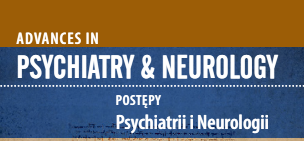

Correspondence to/

Adres do korespondencji:

Karolina Jędrzejczak-Pospiech

Zakład Fizjologii Człowieka

Uniwersytet Medyczny w Łodzi

plac Hallera 1

90-647 Łódź, Polska

e-mail:

karolina.jedrzejczak-pospiech@umed.lodz.pl

Submitted/Otrzymano: 11.08.2017

Accepted/Przyjęto do druku: 21.12.2017

\section{DO CATALASE AND GLUTATHIONE PEROXIDASE PROTECT BLOOD PLATELETS FROM LIPID PEROXIDATION IN MULTIPLE SCLEROSIS?}

\author{
CZY KATALAZA I PEROKSYDAZA \\ GLUTATIONOWA CHRONIĄ PŁYTKI \\ KRWI PRZED PEROKSYDACJĄ LIPIDÓW \\ W STWARDNIENIU ROZSIANYM?
}

\author{
Paweł Fijałkowski, Karolina Jędrzejczak-Pospiech, \\ Jan Błaszczyk
}

Department of Human Physiology, Medical University, Łódź, Poland

Zakład Fizjologii Człowieka, Uniwersytet Medyczny w Łodzi, Polska

\begin{abstract}
Purpose: Catalase (cat) and glutathione peroxidase (GSH-Px) activities and thiobarbituric acid reactive substances (TBARS) concentration in blood platelets were determined in patients with multiple sclerosis (MS).

Methods: The study was carried out in a group of 36 patients, men and women, aged 21-50 years old. They were divided into groups dependently on the degree of motor disability and duration of the disease. The control group included 15 healthy individuals of similar age to the study group. The activity of catalase was estimated according to the method by Beers and Sizer. Glutathione peroxidase activity was determined by the method of Sedlak and Lindsay, modified by Little and O'Brien. The concentration of thiobarbituric acid reactive substances in blood platelets was carried out using the method by Placer et al.

Results: We observed a lower level of TBARS concentration in platelets of MS patients than in control group with an enhanced activities of both antioxidative enzymes on the basis of disability degree and duration of the disease.

Conclusions: Catalase and glutathione peroxidase protect blood platelets from lipid peroxidation process in multiple sclerosis patients and may play a role in the course of the disease. It may also suggest involvement of lipid peroxidation in the activity of multiple sclerosis.
\end{abstract}

Key words: multiple sclerosis, lipid peroxidation, catalase, glutathione peroxidase, thiobarbituric acid reactive substances.

\title{
Streszczenie
}

Cel: Celem badania była ocena aktywności katalazy (cat) i peroksydazy glutationowej (glutathione peroxidase - GSH-Px) oraz stężenia substancji reagujących z kwasem tiobarbiturowym (thiobarbituric acid reactive substances - TBARS) w płytkach krwi u pacjentów ze stwardnieniem rozsianym (multiple sclerosis - MS).

Metody: Badanie przeprowadzono w grupie 36 pacjentów, mężczyzn i kobiet, w wieku 21-50 lat z rozpoznanym stwardnieniem rozsianym. W grupie badanej dokonano podziału w zależności od stopnia niepełnosprawności ruchowej i czasu trwania choroby. Aktywność katalazy oznaczano według metody Beers i Sizer. Aktywność peroksydazy glutationowej określano metodą Sedlaka i Lindsay, zmodyfikowaną przez Little and O’Brien. Stężenie TBARS w płytkach krwi przeprowadzono według metody Placer i wsp.

Wyniki: Zaobserwowano niższy poziom stężenia TBARS w płytkach krwi pacjentów z MS niż w grupie kontrolnej oraz zwiększoną aktywność obu enzymów antyoksydacyjnych, zależną od stopnia niepełnosprawności i czasu trwania choroby.

Wnioski: Aktywność antyoksydacyjna katalazy i peroksydazy glutationowej w płytkach krwi odgrywa rolę ochronną i może być zależna od aktywności stwardnienia rozsianego.

Słowa kluczowe: katalaza, peroksydaza glutationowa, peroksydacja lipidów, stwardnienie rozsiane, płytki krwi, substancje reagujące z kwasem tiobarbiturowym. 


\section{INTRODUCTION}

Multiple sclerosis (MS) is a chronic inflammatory, demyelinating disease of the central nervous system that causes pronounced neurological disability in younger adults. MS is manifested in various forms, such as primary progressive, secondary progressive and relapsingremitting. The last one is the most prevalent form and its clinical manifestation is characterized by recurrent episodes of neurological deficits followed by partial recovery.

It is an immune disorder that is influenced by genetic, immunopathological, biochemical and environmental factors [1-3].

Several hypotheses have been considered to explain the etiology and pathomechanism of demyelination in this disease. It has been suggested that reactive oxygen species (ROS) and increased lipid peroxidation may contribute to the process of demyelination [4-6].

Although the first study of a possible role of platelets in central nervous system demyelination was performed in 1935, the role of platelets in MS was not taken into consideration until 1960s [7]. Presently, blood platelets activation in multiple sclerosis is widely know [8]. Sheremata $e t$ al. tested platelet activation in untreated, stable MS patients. They found that platelets are significantly activated in MS patient, but the mechanisms underlying this activation are still unknown [9].

We also know that blood platelets activated with platelet activating factor (PAF) secreted by macrophages in inflammatory reactions may play a significant role in demyelination [10]. Meyer et al. found that blood platelets taken from patients with MS were able to decrease reactive oxygen species (ROS) production in granulocytes. The process seems to be activated in multiple sclerosis and in other nervous system diseases [11]. Van der Goes et al. noticed that scavenging of ROS with catalase or mannitol decreased the phagocytosis of myelin by macrophages [12].

Two hydroperoxidases are two antioxidative enzymes: catalase (cat) (EC 1.11.1.6) and glutathione peroxidase (GSH-Px) (EC 1.11.1.9) form the first line of cell defense by efficient elimination of hydrogen peroxide $\left(\mathrm{H}_{2} \mathrm{O}_{2}\right)$. Catalase present mainly in peroxisomes of mammalian cells has two enzymatic activities depending on the concentration of $\mathrm{H}_{2} \mathrm{O}_{2}$. If the concentration of $\mathrm{H}_{2} \mathrm{O}_{2}$ is high, catalase acts catalytically and removes $\mathrm{H}_{2} \mathrm{O}_{2}$ by forming $\mathrm{H}_{2} \mathrm{O}$ and $\mathrm{O}_{2}$. On the other hand, it acts peroxidically, when the concentration of $\mathrm{H}_{2} \mathrm{O}_{2}$ is low [13]. However, glutathione peroxidase present in cytoplasm and mitochondrion, eliminates both hydrogen peroxide and lipid peroxides [14].

Bearing in mind all these facts, we decided to perform a study of antioxidative role of blood platelets in multiple sclerosis. The aim of the study was to estimate activities of catalase, glutathione peroxidase and TBARS (one of the products of peroxidation), in blood platelets of MS patients.

\section{METHODS}

The study was carried out at the Department of Human Physiology. The trial was approved by the local ethics committee of the Medical University of Łódź, Poland.

The study group included 36 patients (patients of Department of Neurology and Epileptology), women and men, aged 21-50 years old, suffering from relapsing - remitting multiple sclerosis.

The control group included 15 healthy individuals of similar age to the study group.

The patients were divided into groups dependently on duration of the disease and a degree of motor disability according to Kurtzke scale. In 18 cases the disease lasted up to 6 years (mean 2 years and 7 months), while in remaining cases duration time of the disease was longer than 6 years (mean 12 years and 7 months). Because of differences in degree of motor disability, the patients were divided into 2 groups. First group consisted of 19 patients with 2-4 degree of motor disability, second group consisted of $17 \mathrm{pa}-$ tients with 5-7 degree of motor disability.

The study was carried out during exacerbation of the disease. Patients smoking cigarettes were excluded from the study.

The control group consisted of 15 young, healthy men, aged 19-25 years old, non smokers.

Samples of blood were taken at 6-7 a.m. in amount of about $9.0 \mathrm{ml}$ into Vacutainer tubes containing EDTA. Blood platelets were obtained by centrifuging. Platelet rich plasma (PRP) was prepared by centrifuging in $10 \mathrm{~min}$. at $160 \mathrm{xg}$. Then platelet poor plasma was prepared by centrifuging in $10 \mathrm{~min}$. at $2000 \mathrm{x} \mathrm{g}$. The sediment of platelets was suspended in buffered solution of $0.9 \%$ natrium chloride, $\mathrm{pH}$ 7.4. The activity of catalase (cat) was estimated according to the method by Beers and Sizer [15]. Glutathione peroxidase (GSH-Px) activity was determined by the method of Sedlak and Lindsay [16], modified by Little and O'Brien [17]. The concentration of thiobarbituric acid reactive substances (TBARS) in blood platelets was carried out according to the method by Placer et al. [18]. Platelet measurements were carried out by the Clinical Laboratory. Platelet protein concentration was estimated with the method by Lawry.

The statistical analysis of the results was performed with Statistica 6 PL programme.

\section{RESULTS}

All the measurements revealed the presence of antioxidative blood platelet activation in MS patients. Platelet catalase and glutathione peroxidase seem to play a role in the course of multiple sclerosis. Their activities in blood platelets of MS patients in comparison to the con- 
Do catalase and glutathione peroxidase protect blood platelets from lipid peroxidation in multiple sclerosis?

Czy katalaza i peroksydaza glutationowa chronią płyłki krwi przed peroksydacją lipidów w stwardnieniu rozsianym?

Table 1. Catalase activity in blood platelets with regard to the degree of patients motor disability and duration of the disease. Values in $\mathrm{U} / \mathrm{g}$ platelet protein

\begin{tabular}{|c|c|c|c|c|c|c|}
\hline & \multirow[b]{2}{*}{ Control group } & \multicolumn{5}{|c|}{ A cohort group } \\
\hline & & $\begin{array}{l}\text { All patients } \\
\text { mean }\end{array}$ & $\begin{array}{l}\text { Patients with motor } \\
\text { disability degree 2-4 }\end{array}$ & $\begin{array}{l}\text { Patients with motor } \\
\text { disability degree 5-7 }\end{array}$ & $\begin{array}{c}\text { Patients with duration } \\
\text { time of the disease } \\
<6 \text { years }\end{array}$ & $\begin{array}{l}\text { Patients with duration } \\
\text { time of the disease } \\
>6 \text { years }\end{array}$ \\
\hline$x$ & 9.40 & 22.50 & 19.00 & 26.20 & 18.80 & 26.40 \\
\hline SD & \pm 1.00 & \pm 4.98 & \pm 3.49 & \pm 3.38 & \pm 3.40 & \pm 3.09 \\
\hline$N$ & 15 & 36 & 19 & 17 & 18 & 18 \\
\hline & \multicolumn{2}{|c|}{$p<0.005$} & \multicolumn{2}{|c|}{$p<0.005$} & \multicolumn{2}{|c|}{$p<0.005$} \\
\hline
\end{tabular}

Table 2. Glutathione peroxidase activity in blood platelets with regard to the degree of patients motor disability and duration of the disease. Values in $\mathrm{U} / \mathrm{g}$ platelet protein

\begin{tabular}{|c|c|c|c|c|c|c|}
\hline & \multirow[b]{2}{*}{ Control group } & \multicolumn{5}{|c|}{ A cohort group } \\
\hline & & $\begin{array}{l}\text { All patients } \\
\text { mean }\end{array}$ & $\begin{array}{l}\text { Patients with motor } \\
\text { disability degree 2-4 }\end{array}$ & $\begin{array}{l}\text { Patients with motor } \\
\text { disability degree 5-7 }\end{array}$ & $\begin{array}{l}\text { Patients with duration } \\
\text { time of the disease } \\
<6 \text { years }\end{array}$ & $\begin{array}{l}\text { Patients with duration } \\
\text { time of the disease } \\
>6 \text { years }\end{array}$ \\
\hline$x$ & 18.20 & 45.00 & 40.00 & 50.60 & 44.20 & 45.80 \\
\hline SD & \pm 1.00 & \pm 9.10 & \pm 7.90 & \pm 6.90 & \pm 9.20 & \pm 9.20 \\
\hline \multirow[t]{2}{*}{$\mathrm{N}$} & 15 & 36 & 19 & 17 & 18 & 18 \\
\hline & \multicolumn{2}{|c|}{$p<0.005$} & \multicolumn{2}{|c|}{$p<0.005$} & \multicolumn{2}{|c|}{$p>0.1$} \\
\hline
\end{tabular}

Table 3. Thiobarbituric acid reactive substances (TBARS) concentration in blood platelets with regard to the degree of patients motor disability and duration of the disease. Values in $\mathrm{nmol} / 10^{\circ}$ blood platelets

\begin{tabular}{|c|c|c|c|c|c|c|}
\hline & \multirow[b]{2}{*}{ Control group } & \multicolumn{5}{|c|}{ A cohort group } \\
\hline & & $\begin{array}{l}\text { All patients } \\
\text { mean }\end{array}$ & $\begin{array}{l}\text { Patients with motor } \\
\text { disability degree 2-4 }\end{array}$ & $\begin{array}{l}\text { Patients with motor } \\
\text { disability degree 5-7 }\end{array}$ & $\begin{array}{l}\text { Patients with duration } \\
\text { time of the disease } \\
<6 \text { years }\end{array}$ & $\begin{array}{l}\text { Patients with duration } \\
\text { time of the disease } \\
>6 \text { years }\end{array}$ \\
\hline$x$ & 1.21 & 0.59 & 0.58 & 0.59 & 0.56 & 0.62 \\
\hline SD & \pm 0.09 & \pm 0.13 & \pm 0.12 & \pm 0.14 & \pm 0.13 & \pm 0.13 \\
\hline \multirow[t]{2}{*}{$\mathrm{N}$} & 15 & 36 & 19 & 17 & 18 & 18 \\
\hline & \multicolumn{2}{|c|}{$p<0.05$} & \multicolumn{2}{|c|}{$p>0.1$} & \multicolumn{2}{|c|}{$p<0.05$} \\
\hline
\end{tabular}

trol group were increased (Tables 1,2). We observed also visible differences of activities depending on disability degree and duration time of the disease. In two groups of MS patients, with higher disability degree and longer duration time of the disease, catalase activity was elevated (Table 1). However, the activity of glutathione peroxidase was increased in patients with a higher disability degree, but no differences connected with duration time of the disease were noticed (Table 2). On the other hand, concentration of thiobarbituric acid reactive substances (TBARS) in blood platelets in MS patients was decreased relative to controls. We did not observe any dependence between concentration of thiobarbituric acid reactive substances (TBARS) and a disability degree according to Kurtzke scale, but in the group of MS patients with longer than 6 years duration time of the disease, concentration of thiobarbituric acid reactive substances (TBARS) was increased (Table 3).

\section{DISCUSSION}

In 1991 Toshniwal and Zarling presented an evidence of increased lipid peroxidation in MS [19]. They measured ethane and pentane excretion by patients with MS comparing them to healthy control subjects. Both gases are degradation products of unsaturated fatty acids released during lipid peroxidation. They found that MS patients with acute exacerbation of the disease had significantly higher concentrations of pentane compared to either patients in remission or control subjects. Increased levels of lipid peroxidation products in cerebrospinal fluid and increased erythrocyte peroxidisability were also reported in MS patients [20].

Similar results were obtained by Głąbiński et al. [20]. They found increased generation of the superoxide radical after PMA stimulation in blood of MS patients. However, plasma levels of thiobarbituric acid reactive substances did not differ significantly between MS patients and controls. 
In erythrocytes of MS patients Dudek et al. noticed significantly elevated level of thiobarbituric acid reactive substances in comparison to healthy controls [21].

Increased generation of superoxide radicals may cause demyelination and formation of plaques in the central nervous system. It was noticed that superoxide radicals can selectively damage oligodendrocytes in glial cell cultures. Astrocytes and brain macrophages are not affected and this cytotoxic effect can be completely protected by catalase [22].

Studies of Qi et al. show that both extracellular superoxide dismutase and catalase can protect neurons from process of demyelination and damage of blood-brain barrier can be reduced in 60-70\% [23].

In erythrocytes of multiple sclerosis patients Kopff et al. found that the activity of catalase was decreased, which suggested the decreased level of antioxidative defence in MS patients [24]. Its activity increased in blood red cells of patients after a three-week treatment with adrenocorticotropic hormone (ACTH) [25]. But studies by Syburra and Passi did not show a reduced level of catalase in erythrocytes and plasma [26].

Most of these studies demonstrated a significantly lower mean activity of glutathione peroxidase in erythrocytes of patients with multiple sclerosis than in control groups or patients with various neurological disorders [14, 27-29]. During and after antioxidant therapy its activity increased and was normalized [27, 28].

Our preliminary results published in polish in 1995 presented that low thiobarbituric acid reactive substances concentration in blood platelets in MS patients did not correspond to antioxidative activity of superoxide dismutase (CuZn-SOD) during an exacerbation of multiple sclerosis. Its activity was decreased [30]. These findings suggests that further research concerning antioxidative enzymes is required.

In the latest review Horstman et al. showed that platelets may play a key role in MS and related disorders [31].

Many authors suggest that due to the harmful role of ROS in the pathology of neurodegenerative diseases, antioxidants reduce tissue damage caused by reactive species [32-36]. Some blood cells may play a similar role.

\section{CONCLUSIONS}

Catalase and glutathione peroxidise protect blood platelets from lipid peroxidation process in MS patients and may play a role in the course of the disease. It may also suggest involvement of lipid peroxidation in the activity of MS.

\section{Conflict of interest/Konflikt interesu}

Absent./Nie występuje.

Financial support/Finansowanie

Absent./Nie występuje.

All human and animal studies have been approved by the ethics committee and have been performed in accordance with the ethical standards laid down in the 1964 Declaration of Helsinki and its later amendments.

\section{References/Piśmiennicłwo}

1. Prusiński A. Multiple sclerosis. In: Prusiński A (ed.). Basics of clinical neurology. Warszawa: PZWL; 1998, p. 310-15.

2. Wender M. Demyelinating Diseases. In: Wald I, Członkowska A (eds.). Clinical Neurology. Warszawa: PZWL; 1987, p. 316-333.

3. Wender M, Grądzki J, Pruchnik D. A case of demyelinating disease difficult for classification. Neurol Neurochir Pol 1993; 6: 893-898.

4. Mickel HS. Multiple sclerosis: new hypothesis. Perspect Biol Med 1975; 18: 363-374.

5. Lauer K. A possible paradox in the immunology of multiple sclerosis: its apparent lack of „specificity” might provide clues to the ethiology. Med Hypotheses 1993; 40: 368-374.

6. LeVine SM. The role of reactive oxygen species in the pathogenesis of multiple sclerosis. Med Hypotheses 1992; 39: 271-274.

7. Millar JH, Merret JD, Dalby AM. Platelet stickiness in multiple sclerosis. J Neurol Neurosurg Psychiat 1966; 29: 187-189.

8. Wachowicz B, Morel A, Miller E, Saluk J. The physiology of blood platelets and changes of their biological activities in multiple sclerosis. Acta Neurobiol Exp 2016; 76(4): 269-281.

9. Sheremata WA, Jy W, Horstman LL, Ahn YS, Alexander JS, Minagar A. Evidence of platelet activation in multiple sclerosis. J Neuroinflammation 2008; 5: 27-32; http://dx.doi.org/10.1002/mds.22331. 
10. Cendrowski W. Ethiology and Pathogenesis of MS. In: Cendrowski W (ed.). Multiple sclerosis. Warszawa: PZWL; 1993, p. 62-72.

11. Meyer M, Urbanek K, Hajduch M. Luminol-dependent chemiluminescence of monocytes and granulocytes in multiple sclerosis - the effect of autologus trombocytes. Folia Biol 1991; 37: 3-4.

12. Van der Goes A, Brouwer J, Hoekstra K, Roos D, Van der Berg TK, Dijkstra CD. Reactive oxygen species are required for the phagocytosis of myelin by macrophages. J Neuroimmunol 1998; 92: 67-75.

13. Ścibior D, Czeczot H. Catalase: structure, properties, functions. Postepy Hig Med Dosw 2006; 60: 170-180.

14. Szeiberg A, Golan R, Ben-Ezzer J, Sarova-Pinhas I, Kindler D. Glutathione peroxidase activity in various types of blood cells in multiple sclerosis. Acta Neurol Scand 1981; 63: 67-75.

15. Beers R, Sizer T. Spectrophotometric method for measuring the breakdown of hydrogen peroxide by catalase. J Biol Chem 1952; 195: 133-140.

16. Sedlak J, Lindsay A. Estimation of total protein bound and nonprotein sulfhydryl groups in tissue with Ellmans reagent. Anal Biochem 1968; 26: 192-205.

17. Little C, O’Brien P. Intracellular GSH-peroxidase with a lipid peroxide substrate. Biophys Res Commun 1968; 31: $145-150$.

18. Placer Z, Cushman L, Jonson B. Estimation of product of lipid peroxidation malondialdehyde in biochemical systems. Anal Bioch 1966; 16: 359-364.

19. Toshniwal PK, Zarling EJ. Evidence for increased lipid peroxidation in multiple sclerosis. Neurochem Res 1992; 2: 205-207.

20. Głąbiński A, Tawsek NS, Bartosz G. Increased generation of superoxide radicals in the blood of MS patients. Acta Neurol Scand 1993; 88: 174-177.

21. Dudek I, Zagórski T, Lisiewicz J, Kędziora J, Chmielewski H. Effect of gamma radiation on selected indicators of oxygen metabolism in erythrocytes of patients with multiple sclerosis. Neurol Neurochir Pol 1992; 1: 34-39.

22. Sharpe MA, Ollosson R, Stewart VC, Clark JB. Oxidation of nitric oxide by oxomanganese-salen complexes: a new mechanism for cellular protection by superoxide dismutase/catalase mimetics. Biochem J 2002; 366: 97-107.

23. Qi X, Hauswirth WW, Guy J. Dual gene therapy with extracellular superoxide dismutase and catalase attenuates experimental optic neuritis. Mol Vis 2007; 13: 1-11.

24. Kopff M, Zakrzewska I, Czernicki J, Klem J, Strzelczyk M. Red cell superoxide dismutase and catalase activity in multiple sclerosis. Acta Biochim Pol 1993; 40: 154-157.

25. Kopff M, Zakrzewska I, Czernicki J, Klem J, Strzelczyk M, Chmielewski H. Red blood cell superoxide dismutase and catalase activities in patients suffering from multiple sclerosis treated with adrenocorticotropic hormone. Pol J Pharmacol 1996; 48: 441-445.

26. Syburra C, Passi S. Oxidative stress in patients with multiple sclerosis. Ukr Biokhim Zh 1999; 71: 112-115.

27. Jensen GE, Clausen J. Glutathione peroxidase activity, associated enzymes and substrates in blood cells from patients with multiple sclerosis - effects of antioxidant supplementation. Acta Pharm Toxic 1986; 59: 450-453.

28. Mai J, Sorensen PS, Hansen JC. High dose antioxidant supplementation to MS patients. Effect on glutathione peroxidase, clinical safety and absorption of selenium. Biol Trace Elem Res 1990; 24: 109-117.

29. Mazella GL, Sinforiani E, Savoldi F, Allegrini M, Lanzola E, Scelsi R. Blood cells glutathione peroxidase activity and selenium in multiple sclerosis. Eur Neurol 1983; 22: 442-446.

30. Kędziora J, Fijałkowski P, Buczyński A, Chmielewski H, Lisiewicz J. Certain parameters of platelets oxygen metabolism in patients with multiple sclerosis. Neurol Neurochir Pol 1995; 29: 165-172.

31. Horstman LL, Jy W, Ahn YS, Zivadinov R, Maghzi AH, Etemadifar M, et al. Role of platelets in neuroinflammation: a wide-angle perspective. J Neuroinflammation 2010; 7: 10-86; http://dx.doi.org/10.1186/1742-2094-7-10.

32. Chiurchiu V, Orlacchio A, Maccarrone M. Is modulation of oxidative stress an answer? The state of the art of redox therapeutic actions in neurodegenerative diseases. Oxid Med Cell Longev 2016: 7909380; http://dx.doi.org: $10.1155 / 2016 / 7909380$.

33. Ferretti G, Bacchetti T. Peroxidation of lipoproteins in multiple sclerosis. J Neurol Sci 2011; 311(1-2): 92-97.

34. Gray E, Kemp K, Hares K, et al. Increased microglial catalase activity in multiple sclerosis grey matter. Brain Res 2014 Apr 22; 1559: 55-64.

35. Kostic MS, Rajkovic JS, Potic MS, et al. Multiple sclerosis and oxidative stress - a clinical perspective. Clin Neurol: Neurochem J 2013; 7(1): 76-86.

36. Morel A, Bijak M, Miller E, Rywaniak J, Miller S, Saluk J. Relationship between the Increased Haemostatic Properties of Blood Platelets and Oxidative Stress Level in Multiple Sclerosis Patients with the Secondary Progressive Stage. Oxid Med Cell Longev 2015: 240918; http:// dx.doi.org: 10.1155/2015/240918. 